Krystyna Szcześniak

Uniwersytet Gdański

Katedra Slawistyki

\title{
KALINA OCZYMA SLAWISTY ETNOLINGWISTY
}

\section{ROŚLINY W MAZURACH PRUSKICH OSKARA KOLBERGA}

W pieśniach zebranych przez Oskara Kolberga, znajdujących się w Mazurach Pruskich [Kolberg, 1966], zapisano całą gamę nazw ziół, chwastów, warzyw i zbóż, kwiatów (ogrodowych i rosnących w stanie dzikim), krzewów i drzew. Wielokrotnie obok fitonimów ogólnopolskich pojawiają się tam nazwy gwarowe lub zachowujące cechy fonetyczne regionu, na obszarze którego w czasie osadnictwa zaistniały żywioły: słowiański i bałtycki (litewski, pruski i jaćwieski) oraz niemiecki (osadnicy mówili przy tym różnymi dialektami tego języka). I tak obok legliji, niewatpliwie związanej z pruskim addle, lit. egle, oznaczającej 'drzewo iglaste', a nie jodłę (która na tym obszarze nie rośnie w stanie naturalnym), pojawia się jodła; przy czym z tekstu wynika, iż ten leksem odnosi się prawdopodobnie do świerku. Obok brzozy i kija brzozowego mamy w tychże tekstach byliczkę, chójkę, cebulę, cesowa skrzynkę, damb i stoletni dąb, dębowy kij i dąbrowę, zielony dębek, goździki, groch, grochowiny i grochowiszczyszko, groszek, gryckie, jabłonke, jabłoneckę / jabłoneckie, jarkę, jęcmień i jęczmianny snop, jemiote, jewor obok jawora, kapustę, klon i klonowy listek, konopie, kostrzewę, kruszkę, krusyckę, kruszyczkę i kruszczyczkę, kul, leliję, leluję i lelijowe rzędy, modrą lelię i lelujeckę oraz modrzuchna leliję, a także lelujowy wianek, lelii kwiateczek oraz lelijowy kwiat, lawende i lawendrowy, lewandowy, lewandrowy, lewańdrowy lub lewendrowy wianusecek, len i lenek, leszczyne, lescyne, lescineckę i suchą lesczyneczkę, lipę, lypkę zieloną i lipkę na kolibkę oraz lipowa deske, topiun, wianki macierzanki, mak i kwiat makowy oraz makówkę, maliny, drobniuchny merań, nałyki, które zakściały, a także olsynę, oset, liść osowy, 
owies, owiesek, pasternak i pietruszkę, pokrzywę, polej, przypoludnik, pszenice i psenickie, proso, purzyczki, rokicinę, rozę, rózyckę, czerwoną różę, róży i rozy kwiat, rozany i rózany kwiat oraz rozanowy wianek i razannÿ wianusek, rozmarynkę i kępę rozmaryji, gałązeczkę / wianek z rozmaryi, wianek z siedmiu rumianek i rumianeczek, ruciany wianek i z ruty janecek, drobną rutkę, rzepe, sarcylipan, który swe liście składa, sosnowe kijki i sośnię, szaraniec, tulipany, trzcinę i trzcynę oraz wianusek z kadyku i jałowca (gdzie dwa ostatnie leksemy oznaczają ten sam desygnat), sad wiśniowy, zytko, żytko i żyto.

Jak widać z powyższego wykazu, we wszystkich fitonimach zapisano oprócz cech ogólnopolskich, również charakterystyczne dla tego regionu mazowizmy (nie tylko fonetyczne, ale również leksykalne) oraz cechy północnopolskie. Niektóre nazwy roślin wymagałyby obszerniejszego wyjaśnienia (chójka,jegla, jodła, kadyk) lub podania ich nazw łacińskich (kul, merań, modrzuchna lelija, nałyki, sarcylipan, szaraniec), które ułatwiłyby skojarzenie z konkretnym desygnatem, co mogłoby stać się tematem innej pracy, związanej z tym zbiorem pieśni, ale w tym miejscu, ze względu na podstawowy temat artykułu, mogę to tylko zasygnalizować.

Jednym z częstych fitonimów, pojawiających się w pieśniach mazurskich zebranych przez Kolberga w badanym tomie [Kolberg, 1966, s. 126, 127, 243, $267,269,425,515,519,527,556]$ jest kalina (czasem kalinowy mostek), mająca bogatą kartotekę etnolingwistyczną.

Zdecydowałam się na jej wybór ze względu na piękne, białe kwiaty, mające też odniesienie do obrzędów pogrzebowych - pęk tego kwiecia, choć dziś mogę to zrobić ze zrozumiałych względów tylko symbolicznie, pragnę ofiarować Temu, który wprowadzał mnie w świat prawdziwej nauki, uczył poprzez swe postępowanie, że prawdziwy naukowiec nie zważa na stopień naukowy swego rozmówcy i traktuje go zawsze z jednakowym szacunkiem. Panie Profesorze, dziękuję.

\section{Kalina (Viburnum) jako krzew}

Viburnum rośnie w stanie dzikim (przy sprzyjających warunkach może osiagać cztery metry wysokości) na terenie niemal całej Europy, Azji, Północnej Afryki, a także w Północnej i Środkowej Ameryce; w lasach, między innymi krzewami, a także nad brzegami rzek, choć można go spotkać także na glebach suchych i gliniastych. Przyrodnicy znają około stu dwudziestu pięciu gatunków tego krzewu, żyjącego do pięćdziesięciu lat, choć w Polsce, jak zauważają autorzy Vascular plants of Poland a checklist [Mirek, Piękoś-Mirkowa, A. Zając, M. Zając, 1995, s. 211] występują tylko kalina hordowina (Viburnum lautana) i kalina koralowa 
(Viburnum opulus), będąca, z powodu swego wiosennego kwiecia, jesiennych kolorów liści (od barwy jasnoróżowej do malinowej, koralowej i wręcz purpurowej) oraz owoców, ozdobą miejsc, w których rośnie [Чухно, 2007, s. 216], stąd niektórzy wywodzą jej nazwę od greckiego kalos, kali 'piękny'. Barbara Szczepanowicz [2004, s. 112], autorka Atlasu roślin biblijnych proponuje użycie nazwy kaliny wawrzynowatej (Viburnum tinus, będaccej niewysokim drzewem, rosnącym w lasach na górze Karmel), jako odpowiednika hebrajskiego słowa tidhar (o symbolicznym znaczeniu 'odrodzenie'), które dotychczas thumaczono w Biblii (dwukrotnie w Księdze Izajasza) jako wiąz. Jej zdaniem nowy fitonim lepiej oddaje symbolikę tych tekstów biblijnych.

\section{Kalina w literaturze i kulturze oraz zwyczajach słowiańskich}

Kalina była także natchnieniem dla słowiańskich poetów i autorów różnych pieśni, w tym ludowych - jednym z najbardziej znanych przykładów jest rosyjska piosenka ludowa Kalinka, w której młody chłopak porównuje swą dziewczynę do tego krzewu [http://www.barynya.com/barynya/russian_folk_dance_kalinka. htm (dostęp: 10.09.2014)].

W literaturze pięknej kalina funkcjonuje jako symbol młodości i piękna, od czasu romantyzmu rozszerzono znaczenie symbolu o niewinność, dziewictwo, cierpienie i smutek (związany z przejściem do innego etapu życia), czego przykładem mogą być odpowiednie fragmenty z Balladyny i Beniowskiego ${ }^{1} \mathrm{Ju}-$ liusza Słowackiego. To właśnie z tego czasu wywodzi się też zwyczaj sadzenia kaliny na grobach młodych ludzi (tak dziewcząt, jak i chłopców ${ }^{2}$ ) - miała ona informować przechodniów o czystości duszy zmarłego. Na Podlasiu, ale też w innych stronach Polski, wierzono, że nieopatrzne zerwanie gałązki krzewu z grobu (i tu chodziło nie tylko o kalinę, ale każdy krzew czy kwiat posadzony na grobie ${ }^{3}$ ) miało być przyczyną późniejszych nieszczęść (choroba, kalectwo, a nawet śmierć), spotykających osobę, która to zrobiła. Niekiedy zakazywano z tychże samych przyczyn nawet wąchania kwiecia kaliny, wierząc, iż jest ona jako krzew nagrobny, powiązana ze światem umarłych. $Z$ kolei na północy Rosji i na Ukrainie ${ }^{4}$ sadzono Viburnum w nogach zmarłej młodej dziewczyny, a wcze-

${ }^{1}$ „Oj! nakarmiła się gorzką kaliną! [...]. Cóż? oszukana - ha? kwiatku kaliny, [...]. A czerwieniéjesz teraz jak kalina".

2 W innych stronach Polski (Słowiańszczyzny) krzew ten sadzono tylko na grobach młodych, niezamężnych dziewcząt.

3 Zob. kwestię zerwania kwiatu róży z grobu młodej dziewczyny w tekście Grzędowie. Opowieść z Zimnego Podola [Schoeferowa, 1998].

4 Посадит калину 'pochować kogoś'. 
śniej udekorowane nią weselne drzewko wrzucano do grobu. Kalina stawała się tym samym łącznikiem pomiędzy dwoma światami - życia i śmierci, dlatego też uważana była za skuteczną ochronę przed wszelkimi złymi mocami i stąd sadzono ją chętnie na granicach pól i posesji, a na Ukrainie i w wielu regionach Słowacji i Polski (też na Łemkowszczyźnie) jej gałązkami ubierano domy w dni uważane za czas nasilonego działania demonów i czarownic.

W wielu tekstach słowiańskich kalina występuje jako symbol dziewczęcego piękna [Раговіч, 2002], miłości i szczęścia, a takiemu widzeniu sprzyja biel jej kwiatów, zebranych w piękne białe kule (Schneebale) oraz czerwona barwa owoców, przyciągających zimą wiele gatunków ptaków ${ }^{5}$. W literaturze polskiej jest ona tytułowym krzewem wiersza Teofila Lenartowicza, towarzyszącym Jaśkowi od narodzin do śmierci. Do tego tekstu muzykę skomponował Ignacy Komorowski, na którego nagrobku na warszawskich Powązkach wykuto napis „Śpiewakowi kaliny ziomkowie”. Z kolei w powieści Elizy Orzeszkowej Nad Niemnem pojawia się pieśń znana nie tylko w regionie grodzieńskim: „Ty pójdziesz góra, ty pójdziesz górą, a ja doliną, Ty zakwitniesz różą, ty zakwitniesz różą, a ja kaliną [...]”. Jej też poświęcił jedną ze swych pieśni (opublikowaną w roku 1952 w cyklu Pieśni kurpiowskie) Kazimierz Sikorski [1952]. Kalina oznaczająca 'młodą dziewczynę' pojawia się także w jednym z przysłów (Pan Bóg za gline, ja za kalinę) zebranych przez Samuela Adalberga, które wypowiada wdowiec po śmierci niemłodej już żony [za: Ziółkowska, 1983].

Warto dodać, iż w ludowych pieśniach Słowiańszczyzny dziewczynę, pannę młodą nazywa się często kaliną. Narzeczony, swatowie i drużbowie jadą przez kalinowy zagajnik, który ma w tych tekstach wyraźną wymowę erotyczną, zatem nie dziwi fakt, iż w niektórych ukraińskich pieśniach weselnych pojawia się wątek kaliny, która prosi drużki, by wzięły ją (gałązkę, kwiaty lub jagody) na dekorację korowaja. $Z$ kolei w pieśniach kozackich jest ona często symbolem przelanej krwi - umierający poza granicami swego kraju Kozak prosi o to, by ptaki, przelatując nad miejscem jego śmierci jadły kalinę i przynosiły mu wieści z kraju ojczystego. Kalinowy most w ludowych pieśniach wschodnich Słowian ma znaczenie przejścia, miedzy granicznej, przy czym pierwotnie była to granica między tym a tamtym światem, a później (takiego znaczenia nabiera on na przykład w pieśniach weselnych) oznacza już zapowiedź zmiany stanu, przejście młodej dziewczyny do grona mężatek.

Szczególnie często siadają nań drozdy, rudziki, piegża, pokrzewka oraz sroka i muchołówka szara. Liście i korę zjadają bobry, kuny leśne oraz inne gryzonie i owady. 
W zamowach, które możemy potraktować jako teksty zawierające przejściowe znaczenie tego terminu - na kalinowym moście toczą się potyczki o życie i zdrowie osoby lub leczonego zwierzęcia (święty Jerzy walczy na nim z wiedźmą mleczną, która, jak wierzono, miała moc odbierania krowom mleka ${ }^{6}$ lub występują tam trzy siostry dziewice, wstrzymujące krew i niszczące w ten sposób działanie klątwy [Беларускі фальклор, 2005, t. I, s. 617-618; Толстой, red., 1999, s. 448]).

Potocznie zwana wśród Słowian kaliną, kalina koralowa, łac. Viburnum opulus, jest wyjątkowo wyraziście zapisana w ich kulturze, szczególnie jako symbol młodości i piękna. W mitologii słowiańskiej krzew ten uważano za roślinę Słońca; niektórzy badacze wywodząjej nazwę od koła (pod taką figurą ukrywano często Słońce) i dlatego krzew ten traktowano jako święty, nietykalny. Oszczędzać miał ją nawet piorun, który nigdy miał w kalinę nie uderzać, i jak wierzono, można było w jej gąszczu znaleźć bezpieczne schronienie podczas burzy. Przez znachorów była uznawana za drzewo magiczne, które przejmowało troski i zmartwienia żalącej się pod nim kobiety ${ }^{7}$, a jej owoce miały zabezpieczać gospodarstwo i domowników przed klątwą i działaniem sił nieczystych [Мазнев, 2004, s. 199]. Te same jagody przypominały obserwatorom krople krwi, symbolizując narodziny, życie a nawet śmierć, a według powszechnego przekonania w kalinę wcielała się po śmierci dusza niezamężnej młodej kobiety ${ }^{8}$. W tym kontekście motyw kalinowej gałązki z jagodami występuje w zdobnictwie, między innymi w hafcie, zwłaszcza na wschodzie Europy, zaś w kulturze Ukrainy kalinę uważa się do dziś za znak żywotności i trwania narodu. Na Kujawach kalinę kojarzono ze smutkiem i cierpieniem, dziewictwem i skromnością, a podania (podobnie jak na wschodniej Słowiańszczyźnie) przekazywały informację, iż po śmierci dziewczyna zmienia się w krzew kaliny. Znany jest też (nie tylko z tego regionu) motyw krwawiącej skaleczonej gałęzi kaliny, płaczącej i skarżącej się dziewczęcym głosem.

6 Za taką czarownicę uznano w Dziurdziach Elizy Orzeszkowej żonę kowala, co spowodowało oskarżenie jej przez współmieszkańców o czary, a potem zabicie młodej, pomocnej innym dziewczyny. O wiedźmach mlecznych i walce z nimi zob. szerzej [Колосова, 2009, s. 215].

7 „Если тебе тяжело, горько от судьбы своей, обими калину-матушку, проведи несколько раз по ее стволу, поведай-открой все тайны свои горькие, прижмись к ней осторожно, не поломав веточек, сразу станет легче на душе" - taką radę dawano kobietom, gdy przychodziły do szeptunki ze swoimi kłopotami, dodając, iż najlepiej do kaliny podchodzić w dni ciepłe, suche i niedeszczowe w pierwszej połowie dnia, zaś najlepszymi miesiącami są sierpień i wrzesień [Мазнев, 2004, s. 199].

8 Kalina wiosną okrywa się białymi kwiatami, symbolem młodej dziewczyny, zaś jesienią pojawiają się na niej czerwone owoce, z których na Białorusi robiono korale, nakładane zmarłej dziewczynie do trumny [Беларускі фальклор, 2005, t. I, s. 617-618]. 
Ze względu na to, że pesteczka owocu kaliny przypomina swym kształtem serce, na Rusi rubinowe owoce krzewu stały się symbolem męstwa ludzi, którzy oddali swe życie w walce $\mathrm{z}$ wrogami. Na terenie Ukrainy opowiada się legende o tym, jak młode, niezamężne dziewczyny wyprowadziły na nieprzebyte bagna oddziały tatarsko-mongolskich napastników i ginąc (wraz z nimi) zamieniły się w okryte wiosną białym kwieciem krzewy, które jesienią zdobione były czerwonymi, koralowymi jagodami (symbolicznie oznaczającymi męczeńską śmierć) kaliny miały powstać z krwi odważnych dziewcząt. Inna legenda, pochodzaca już z kregów zachodniosłowiańskich, mówi, że purpurowa barwa owoców Viburnum powstała z krwi pewnej męczennicy za wiarę, a sam krzew zyskał miano od jej imienia. Można przypuszczać, iż to właśnie podanie znał Henryk Sienkiewicz, który późniejszej Ligii, bohaterce Qvo vadis nadał imię Kalina, które nosiła, zanim trafiła jako zakładniczka do Rzymu.

Należy tu jednak przypomnieć, że nawet na blisko sąsiadujących ze sobą obszarach Słowiańszczyzny różnie odnoszono się do tego krzewu. I tak na przykład w okolicach Brześcia (Białoruś) chętnie sadzono kalinę w pobliżu domu, jako że miała ona dobrze wróżyć tak gospodarstwu, jak i jego mieszkańcom, chroniąc od sił nieczystych; ale już w sąsiedztwie Homla (też Białoruś) ostrzegano przed jej sadzeniem w pobliżu domu, bo wierzono, iż stojąca na granicy dwóch światów kalina może do siebie przyciagnać gospodynię. Z podobnych przyczyn, jak można mniemać, zakazywano ścinania Viburnum (pod groźbą śmierci) na Grodzieńszczyźnie i w okolicach Kijowa, choć ów zakaz oficjalnie thumaczono tym, iż jej owocami żywią się ptaki. W Bułgarii sadzono ten krzew bez oporu dla dekoracji otoczenia domu, a obecnie w ogródkach przydomowych i parkach na Pomorzu można również zauważyć wiele odmian tego krzewu.

Jeśli chodzi o obrzędy kalendarzowe, to owoce i gałązki kaliny są obecne w różnych świętach na obszarze Słowiańszczyzny. U Bułgarów babka ('położna') przed babinym dniem ${ }^{9}$ odwiedzała wszystkie domy, w których przyjmowała dzieci na świat i mazała czoło tak matkom, jak i dzieciom, kaszą z jagód kaliny, zapraszała ich do siebie i błogosławiła. U Hucułów zwierzęta, które wprowadzano do domu w dzień Nowego Roku strojono na szczęście w kalinę, barwinek, wstążki, kłosy zbóż. W dzień Chrztu Pańskiego w Tarnopolskiem młode kobiety i dziewczyny zapalały w wodzie trzy świece, związane gałązkami kaliny i zasuszonymi kwiatami, a potem myły w niej dla urody twarz i ręce, wrzucając

9 Przypadał on na ósmego (21) stycznia. Dzień ten był dedykowany babce, położnej, a uczestniczyły w nim kobiety mające dzieci, które przyjmowała na świat (babiła) owa położna, rzadziej brzemienne, a główną postacią święta była wspomniana babka. W trakcie takich spotkań pojawiały się wspólne kąpiele, oblewanie wodą, co łączono z symboliką oczyszczania po porodzie. 
przedtem doń korale kaliny. Z kolei Czesi na Niedzielę Palmową chrzcili bydło w oborze, chlewie i stajni poświęconymi przedtem w kościele gałązkami kaliny $\mathrm{i}$ innych drzew, wierząc, że po tym zabiegu będzie ono zdrowe, a dopiero potem palemki wnoszono do domu, gdzie przechowywano je przez cały rok. Słowacy z kolei pisali woskiem kalinę na pisankach wielkanocnych [Толстой, red., 1999, s. 446-448].

W okolicach Radomska w dzień Zielonych Świątek (Zesłanie Ducha Świętego), a na innych obszarach w wigilię św. Jana Chrzciciela, dekorowano domy i obejścia gałązkami kwitnącego w tym czasie krzewu, zaś w okolicach Kurska (Rosja) rozrzucano gałązki kaliny dla dobrego urodzaju po polu. Na Białorusi dziewczęta szły palić sobótki w koralach z jagód kaliny ${ }^{10}$ wierząc, że tak przystrojone są bezpieczne od czarów, zwłaszcza miłosnych. W Rzeszowskiem wplatano w wieniec dożynkowy korale kalinowe, a w Małopolsce gałązki kaliny z owocami wchodziły w skład bukietów święconych 15 sierpnia podczas Święta Matki Boskiej Zielnej [Paluch, 1984].

W obrzędowości rodzinnej, szczególnie Słowian wschodnich i południowych, kalina była symbolem piękna, czystości i przedłużenia rodu [Раговіч, 2002]. Kiedy w rodzinie rodziła się tam dziewczynka, zasiewano kalinę, a do pierwszej kapieli dziecka kładziono jagody i liście krzewu, aby było ono rumiane, szczęśliwe i zdrowe. Położna, obmywając twarz i ręce położnicy, życzyła jej rumieńca jak czerwień kaliny, wieszając jej owoce lub kwiecie nad dziewczynką i położnicą w celu zapewnienia im zdrowia i szczęścia. Na chrzcinach - chrzestnym oraz gościom rodzina dziecka darowywała ciasteczka w kształcie szyszek z wetkniętymi doń kwiatkami lub owocami kaliny i wspólnie śpiewano pieśni o kalinie.

W tradycyjnej kulturze, zwłaszcza Słowian Wschodnich, kalina uważana była za krzew żeński, a szczególnie symbol dziewczyny - życiodajnej siły i płodności. Ważną rolę odgrywa ona na Białorusi i Ukrainie właśnie w obrzędach ślubno-weselnych [Раговіч, 2002]. Nie dziwi zatem, że w świadomości tych Słowian wschodnich kalinę wykorzystywano jako dekorację stołu weselnego, symbolizującego kolejne przejście w życiu młodej dziewczyny; ozdabiano nią korowaj, świece weselne i drzewce (laskę weselną), potrawy weselne oraz wplatano ją do wianka (razem z barwinkiem) i zdobiono uprzęże koni, wiozących młodą parę oraz gości weselnych do ślubu, a druhny i przyjaciółki panny młodej wplatały kalinę w warkocze. Przed parą młodych stawiano też bukiety z jagodami kaliny jako symbol piękna duchowego, radości, szczęśliwego życia

10 Nazwa tego krzewu często pojawia się w przyśpiewach, refrenach w białoruskich pieśniach sobótkowych i kolędowych („Каліна, ой ель мая зялёная, каліна!; Каліна зялёная - ягада чырвоная, Каліна!”) [Беларускі фальклор, 2005, t. I, s. 615]. 
rodzinnego. Wywieszona na domu gałązka kaliny była znakiem, iż tu wydawana jest dziewczyna za mąż [Мазнев, 2004, s. 199]. Na Białorusi w trakcie wesela, w obrzędzie Камора, poprzedzającym noc poślubną i po niej, śpiewano pieśni, mające wyraźnie erotyczny podtekst, nawiązujący do czerwieni jagód, a związany z zachowaniem czystości przez pannę młodą: „Не цвіла калінанька к Пятру, да зацвіла калінанька к Раздву, 3 Мар'юхнаю нашага Іванка ў каморы, У нашай Мар'юхны ў падоле”. W innej pieśni z Białorusi pojawia się „каліна без ветру буйна”, która jest panną młodą „ад бацькоў чэсна” i która „не давала каліны нікому, а несла яе ў свякраткіну харому”. Taką dziewczynę, która „вынесла калінаньку, звесяліла радзінаньку, вынесла чырвоную, звесяліла раджоную" poważano i szanowano również w rodzinie, do której weszła [Беларускі фальклор, 2005, t. I, s. 615].

W tym też kręgu kulturowym kalina zwano czerwoną wstążkę (Wołyń), a także urodę panny młodej, samą dziewczynę, narzeczoną i koszulę mołoduchy po nocy poślubnej, będącą świadectwem jej dziewictwa. Stąd też określeniami złamać kalinę, utracić kalinę nazywano na obszarach wschodniej Słowiańszczyzny (szczególnie na Ukrainie) 'deflorację, utratę dziewictwa', a chodzenie po kaline, branie, tamanie czy rabanie kaliny oznaczało 'wydawanie dziewczyny za mąż'. Na Białorusi powiedzenie: ścięta, złamana lub schylona kalina oznacza 'młodą mężatkę', zaś kalina nierozkwitnięta lub ponacinana, przekwitnięta czy niedojrzała albo poczerniała była w pieśniach weselnych zielem nieszczęśliwym, oznaczała pannę młoda, która nie dochowała czystości [Беларускі фальклор, 2005, t. I, s. 615]. Na Ukrainie rodzice pana młodego po nocy poślubnej młodej pary, jako symbol zachowanego dziewictwa przez pannę młoda, posyłali rodzicom dziewczyny butelkę wina z przywiązaną doń kiścią kaliny i kłosami zboża. Informację o niewinności panny młodej (jesienią i zima) przekazywano czasem poprzez wysypywanie podwórka weselnego domu kiśćmi owoców, zaś wiosnąkwiatami kaliny. Na Wołyniu pozytywne wieści w tej kwestii przynosiła kura pomazana krwią i z przywiązanym doń pęczkiem kaliny oraz fragmentem koszuli panny młodej. W rejonie Oranienburga po nocy poślubnej strojono figurę, którą ubierano w koszulę panny młodej, zaś rodzice mołoduchy częstowali wówczas gości nalewką z kaliny [Толстой, red., 1999, s. 446-448].

Jeśli dziewczyna zachowała niewinność, to w okolicach Krasnodaru obnoszono po wsi drzewko ozdobione jagodami kaliny i koszulą panny młodej, a ona sama smarowała twarz młodego jagodami kaliny. Jeśli jednak nie dochowała czystości, twarz młodej była przez młodego smarowana jagodami, a ponadto uczestnicy wesela zrzucali kalinę z korowaja, naczyń i ozdób weselnych a nawet czepca i deptali jagody lub kwiaty, a na ich miejsce wtykali gałązki sosny lub 
rutę. Niekiedy dodatkowo złośliwie druhny śpiewały: „Да ходзімо до плота, Да розадремо кота. Занесемо під перыну. Да зробимо калину". Na trzeci dzień po ślubie w okolicach Woroneża odprawiano obrzęd rozpijania kaliny, który polegał na podchodzeniu wszystkich obecnych do młodej pary i wypijaniu kieliszka wódki z włożonymi doń jagodami kaliny, które zjadano [Толстой, red., 1999, s. 447].

\section{Viburnum w lecznictwie ludowym, homeopatii i medycynie oficjalnej}

Roślinie tej przypisywano już od czasów starożytnych liczne właściwości lecznicze, niezależnie od siebie odkryte w różnych regionach świata (w Europie, na Dalekim Wschodzie i Ameryce Północnej), choć początkowo wiązano je wyłącznie z Viburnum prunifolium, kalina śliwolistna (do Europy sprowadzano jej korę z Ameryki Północnej). Dopiero w XIX wieku pojawiły się naukowe opracowania wskazujące na lecznicze właściwości również kaliny koralowej, ale chociaż w roku 1858 w Rosji była już zalecana jako środek przeciwrakowy, to jeszcze 20 lat później zalecano sporządzanie leku przeciw dusznicy bolesnej z liści kaliny śliwolistnej. W roku 1928 oficjalnie już stwierdzono, że kalina koralowa (Viburnum opulus) nie ustępuje w działaniu jej odmianie Viburnum prunifolium.

Pijar Remigiusz Ładowski (1738-1798) umieścił kalinę między innymi w swoim dziele Historia naturalna Królestwa Polskiego, jako niezawodny środek na różne schorzenia, zalecając zwłaszcza picie naparów z kory i kwiatu na różne kobiece dolegliwości, pisząc tam, że ,na Litwie zbierają na zimę kaliny wiązkami i używają na różne lekarstwa" [www. domzgliny.zafrico.pl (dostęp: 10.09.2014)].

Kalina koralowa (rosnąca w naszym obszarze klimatycznym) stosowana była w medycynie ludowej (tak zwanym lekarowaniu) do celów leczniczych dużo wcześniej, niż w medycynie oficjalnej w postaci soków, wywarów, naparów, nalewek i odwarów z różnych elementów tego krzewu. W rejonie Olkusza przemrożone owoce do dziś zaleca się spożywać dzieciom przy robaczycy, zaś świeże owoce są używane na obszarze całej Słowiańszczyzny do przyrządzania kisieli, marmolad, dżemów, dekoracji ciast i nadziewania cukierków oraz pierogów [Ziółkowska, 1983]. Wiedziano, że działają one lekko moczopędnie i wzmacniają mięsień sercowy, a 10-20\% roztwory soku zalecano do stosowania zewnętrznego przy leczeniu chorób skóry. Przetwory z owoców polecano przy przeziębieniach, skurczach jelit i żylakach odbytu oraz innych krwawieniach wewnętrznych i z nosa, również na obszarze dzisiejszej Polski, a powidła sporządzone z jagód kaliny uważa się do dziś w ludowej medycynie za znakomity środek przeczyszczający. Przy zapaleniach górnych dróg oddechowych oraz płuc i chorobach wątroby zalecano spożywanie jagód wsypanych do rozgrzanego 
miodu (po 6-7 godzinach), zaś świeże jagody stosowano również przy awitaminozie, w celu wzmocnienia organizmu i jako środek lekko moczopędny [Мазнев, 2004, s. 198].

Z ziaren owoców przyrządza się na całym obszarze Słowiańszczyzny wschodniej namiastkę kawy, pitą przy kłopotach z prawidłowym funkcjonowaniem jelit i złą przemianą materii (szczególnie przy zaparciach), zaś herbatę z liści i jagód zalecano przy bólach gardła [Чухно, 2007, s. 217].

Położnice oraz osoby cierpiące na krwotoki i tym podobne schorzenia [www. domzgliny.zafrico.pl (dostęp: 10.09.2014)] piły napary z liści i owoców kalinowych (jagody mrożone i suszone zachowywały swe wartości lecznicze do roku, zatem przechowywano całe gałęzie kaliny lub same owoce na strychach lub w innych pomieszczeniach) [Чухно, 2007, s. 216-217], co wskazuje na wykorzystywanie w medycynie ludowej sygnatury Paracelsusa (leczenie tego samego przez to samo).

Na obszarze współczesnej Polski napar z liści i owoców stosuje się przy zapaleniu gardła, zaś na terenie wschodniej Słowiańszczyzny napar z samych owoców - przy arteriosklerozie, kłopotach gastrycznych, chorobie wrzodowej żołądka i dwunastnicy oraz przeziębieniach. Z kolei naparem z kwiatów przemywa się wrzody, rany i pije się go przy różnego rodzaju wysypkach na skórze [Мазнев, 2004, s. 199], a także przy kaszlu, gruźlicy, sklerozie i chorobach żołądka [Чухно, 2007, s. 217].

Wiejskie szeptunki i lekarzychy zalecały spożywanie przemrożonych owoców kaliny w postaci odwaru gotowanego z miodem przy przeziębieniach, kaszlu, chrypce, dusznościach, biegunce, żółtaczce, a górale w rejonie Czarnego Dunajca do dziś piją odwar z owoców przy zimnicy ${ }^{11}$. Na Rusi polecano wywar z kory wcierać w skórę głowy, co miało skutecznie wpływać na pozbycie się łysiny i przywracać bujność czupryny. W ludowej medycynie rosyjskiej odwary najbardziej popularne sąjednak wśród kobiet, stąd kalina nazywana jest tu lekiem kobiecym. Przygotowuje się je bądź z korzeni (łagodzą wówczas dolegliwości menstruacji, zapobiegają również poronieniom, krwawieniom związanym z klimakterium, skurczom nóg podczas ciąży, niepowstrzymanym wymiotom ciężarnych i zaburzeniom nerwowym w czasie ciąży; leczy się nimi ponadto skazę limfatyczna, drgawki, histerię, bezsenność i astmę), bądź z kwiatów (poprawiają trawienie i zalecane są w źródłach rosyjskich przy skurczach jelit, biegunkach, także jako środek wykrztuśny, napotny i pomocny w chorobach kobiecych), bądź

11 Zbiór surowca $\mathrm{z}$ roślin dziko rosnących w Polsce wymaga w związku z ochroną prawną tego gatunku uzyskania odpowiednich zezwoleń, o których mowa w ustawie o ochronie przyrody. 
z kory zbieranej wczesną wiosna, suszonej i zwijanej w charakterystyczne rurki (odwar pity małymi dawkami zalecano przy krwotokach z nosa, dla obniżenia cholesterolu we krwi i poprawy przemiany materii; ułatwia on zasypianie i uspokaja) [Мазнев, 2004, s. 199]. Podobne zastosowania mają odwary z kory kaliny w leczeniu chorób narządów oddechowych zwierząt, a ponadto kora, liście i owoce używane są do leczenia pryszczycy u bydła.

Homeopatia wykorzystuje nalewki z owoców kaliny, którymi leczy się skurcze mięśni, choroby kobiece, a także używa się jako środka zapobiegającego poronieniom. Wyciągi wodne i alkoholowe z kory kaliny wykazują słabe działanie cytotoksyczne, zaś wzbogacone o owoce mają silne działanie antyoksydacyjne.

Zebrany materiał pozwala na stwierdzenie, iż krzew ten, zapisany w tekstach pieśni mazurskich zebranych przez Oskara Kolberga (pochodzących zatem z obszarów o wpływach kulturowych polskich, bałtyckich i niemieckich) występuje tam w tych samych symbolicznych znaczeniach, co w całej w kulturze słowiańskiej, szczególnie w tekstach dotyczących obrzędowości ślubnej i weselnej. Różnice występują w ocenie przyjazności Viburnum dla otoczenia, jako że w pewnych częściach Słowiańszczyzny (nierzadko w niewielkich odległościach od siebie) dominuje lęk przed krzewem rosnącym na granicy dwóch światów - co mocno akcentują połączone barwy: zieleń, czerwień, biel i czerń. Kolorystyka ta, odbierana symbolicznie, pojawia się zwłaszcza w ludowych strojach ukraińskich, choć można zauważyć jej elementy także w strojach bułgarskich i rosyjskich. Okazało się także, że właściwości Viburnum w podobny sposób wykorzystywane były w całej Słowiańszczyźnie w lecznictwie ludowym i oficjalnej medycynie, a wszystkich jego elementów (liści, kory, kwiatów i owoców, a nawet ich ziarenek) używano w postaci naparów, wywarów, odwarów, soku i przetworów przede wszystkim (choć nie tylko) w leczeniu kobiet - tak zewnętrznie (do okładów), jak i wewnętrznie.

\section{BIBLIOGRAFIA}

Беларускі фальклор, 2005, t. I-II, Мінск.

Чухно Татьяна, 2007, Лекарственные растения. Иллюстрированный энциклопедический словарь, Москва.

Колосова В.Б., 2009, Лексика и символика народной ботаники, Москва.

МАзнев Николай И., 2004, Энциклопедия лекарственных растений, Москва. Mirek Zbigniew, Piękoś-Mirkowa Halina, Zając Adam, Zając Maria, 1995, Vascular plants of Poland a checklist, Krytyczna lista roślin naczyniowych Polski, Kraków. 
PAluch Adam, 1984, Świat roślin w tradycyjnych praktykach leczniczych wsi polskiej, „Acta Universitatis Wratislaviensis”, Wrocław.

РАговгч У.І., 2002, Песенны фальклор Палесся, t. I-II, Мінск.

Schoeferowa Maria, 1998, Grzędowie. Opowieść z Zimnego Podola, Warszawa. SiкоRSKI Kazimierz, 1952, Kalina, melodia kurpiowska na chór mieszany a capella, Biblioteka Polskiej Piosenki, http://www.bibliotekapiosenki.pl/ Sikorski_Kazimierz_Wincenty_Kalina_melodia_kurpiowska_na_chor_mieszany_a_cappella (dostęp: 10.09. 2014).

Szczepanowicz Barbara, 2004, Atlas roślin biblijnych. Pochodzenie. Miejsce w Biblii i symbolika, Kraków.

Толстой Н.И., red., 1999, Славянские древности. Этнолингвистический словарь, t. 2, Москва.

ZıóŁKowsKa Maria, 1983, Gawędy o drzewach, Warszawa.

www. domzgliny.zafrico.pl (dostęp: 10.09. 2014).

Russian folk song and dance „Kalinka” (ang. Barynya), http://www.barynya.com/ barynya/russian_folk_dance_kalinka.htm (dostęp: 10.09. 2014). 